\title{
Trend Analyses of Parameters of Equations for Overall Fairness Ratio Achievable in Ubicomp MANETs Using Location-Aware Transmission.
}

\author{
M. Kaleem GALAMALI, Assoc. Prof Nawaz MOHAMUDALLY
}

\begin{abstract}
The fields of location-tracking, ubicomp functionalities and MANET transmission strategies are prone to quite a lot of productive research [37-73]. It still remains unrefutable that the engineering portion of modelling in ubicomp to scrutinise predictability properties is at its inception phases. The sub-portion of energy management is distinctively important since in present technology, battery power is still considered constrained. Formerly, an investigation was conducted to quantify and model the Overall Fairness Ratio (OFR) of energy consumption recordable for CBRs for node densities of 7 until 56. The corresponding model was observed to be a combination of exponentially and linearly increasing tendencies.
\end{abstract}

In this paper, the next milestone of investigation is expressed as: "What are the trends of variation observable within each parameter of the equations of curves obtained for metric OFR [21] over varying node densities?"

Studying the demeanor of constituents of applicable models for metric OFR and successively model the observed behaviour of each constituent mathematically is very consequent as it necessitates huge efforts and disagreement resolution among researchers. The results put forward will aid designers towards more profitable understanding of ubicomp and prepare hardware and algorithmic support for ubicomp architecture. This paper is a follow-up of previous research [1-36].

Key terms: Ubicomp- Ubiquitous Computing, MAUCMobile and Ubiquitous Computing, MANET- Mobile Adhoc Network, CBR- Constant Bit Rate, OFR- Overall Fairness Ratio.

M. Kaleem GALAMALI,

University of Technology Mauritius (student) Mauritius

Assoc. Prof Nawaz Mohamudally University of Technology Mauritius, Mauritius

\section{Introduction}

MANETs remain a fulfilling solution to scant resource availability in ubicomp, whereby energy consumption load is distributed among nodes present in the topography. In situations of such cooperation, the criteria of Fairness crops up. One feature for fairness is how many contributing nodes are spending more energy than the sender and those spending less energy than the sender in the topography. An anterior study [21] was undertaken with the aim of finding the trends observable for metric OFR for node densities ranging from 7 until 56. The trend followed in that paper [21] was noted to be increasing and the model equation put forward combined the exponential and linear models.

$F(x)=a * \exp (b * x)+(c * x)+d$

Here, the equations of the model has involved 4 parameters: a, b, c and d. The next quest required for metric OFR is the derivation of model equations for the parameters of the equation mentioned above.

The key contributions of this paper is the establishment of the trend of variation for each parameter of the equations involved in the model for metric OFR presented in former paper [21] whose table 1 is readopted here. The mathematical procedures put up in this paper may feasibly be inserted into software simulators, thereby, providing and additional utility for designers to better understand the evolution and predictability of ubicomp characteristics to promote in better equipping future ubicomp architecture. The rest of this paper is organised as follows: section 2Parameter Trend Analysis- Metric OFR, section 3Conclusion and References.

\section{Parameter Trend Analysis - Metric ECR.}

2.0 General Procedure Adopted.

Firstly, the tabulated data for each parameter of equations for the model for OFR is plotted on gnuplot. Secondly, graphical analyses are carried out and general observations are detailed. Thirdly, various equations of fit are tried. Choice of best fit was made depending on value of reduced chi-square and a combination of projected parameter values at higher node numbers. Fourthly, the values of parameters for each OFR parameter of equation is noted.

\subsection{Trend Analysis - OFR parameter " $a$ ".}

The curve obtained depicts a clean oscillation along a straight line with positive gradient as axis of oscillation. 
Proc. of The Sixth Intl. Conf. On Advances In Computing, Control And Networking - ACCN 2017 Copyright (C) Institute of Research Engineers and Doctors, USA .All rights reserved. ISBN: 978-1-63248-117-7 doi: 10.15224/ 978-1-63248-117-7-01

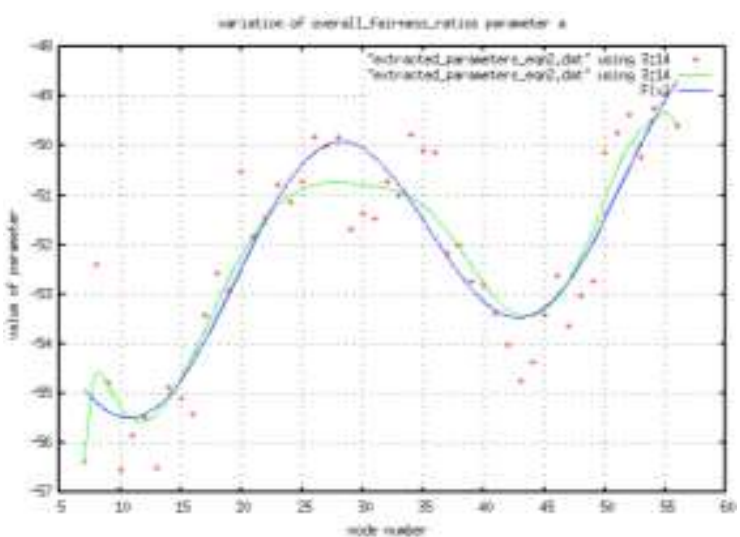

Figure 1: OFR parameter a

The potentially applicable equations are:

1. $F(x)=3{ }^{*} \cos (2 * x)+2 \star x+1$ Initial iteration bringing only partial progress

2. $F(x)=a * \cos (b *(x+f))+C * x-d$

Ch_sq $=0.977308 \quad \mathrm{~F}(80)=-50.360$

$\mathrm{F}(100)=-47.80186$

\section{Choice of best fit for OFR parameter a}

Of course, the equation in part 2 above has been selected because of good enough ch_sq and good extendability. The parameters for best fit are:

$\mathrm{a}=2.26178, \mathrm{~b}=0.196123, \mathrm{c}=0.0630595, \mathrm{~d}=$ $53.938, \mathrm{f}=4.50324$.

\subsection{Trend Analysis - OFR parameter " $b$ ".}

At the start of the curve, there is a decreasing tendency until a minimum point is reached, following which the curve increases at a decreasing rate.

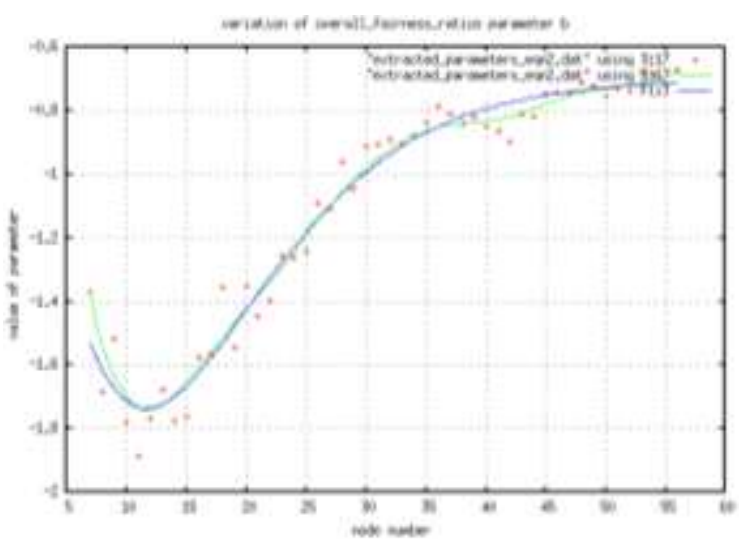

Figure 2: OFR parameter b

The potentially applicable equations are:

$$
\begin{aligned}
& \text { 1. } F(x)=a \star x \star \exp (b \star x)+c \\
& \text { Ch_sq }=0.00794229 \quad \mathrm{~F}(80)=-0.618009 \\
& \mathrm{~F}(100)=-0.61251029 \quad \mathrm{~F}(120)=-0.61162 \\
& \text { 2. } F(x)=a * x * \exp (b *(x-c))+d \\
& \text { Ch_sq }=0.00811494 \\
& 3 \cdot F(x)=a^{\star} x^{\star} \exp (b \star x)+\left(c^{\star} x\right)+d
\end{aligned}
$$

$$
\begin{array}{rl}
\text { Ch_sq }=0.0141253 & F(80)=-2.95 \\
F(100)=-12.1149 & \\
\text { 4. } F(x)=a x^{2} \star \exp & (\mathrm{b} * \quad(\mathrm{x}-\mathrm{C}))+\mathrm{d} \\
\text { Ch_sq }=0.00495352 & \mathrm{~F}(80)=-0.701009178 \\
\mathrm{~F}(100)=-0.7006468 & \mathrm{~F}(120)=-0.7006286
\end{array}
$$

\section{Choice of best fit for OFR parameter $b$}

The equation in part 4 above has been selected because of both smallest reduced chi-square value obtained and good extendability. The parameters for best fit are:

$\mathrm{a}=-0.05573, \mathrm{~b}=-0.17207, \mathrm{c}=0.100375, \mathrm{~d}=-$ 0.700628

\subsection{Trend Analysis - OFR parameter " $c$ ".}

Generally the curve depicts a smoothly decreasing tendency with decreasing rate of decrease.

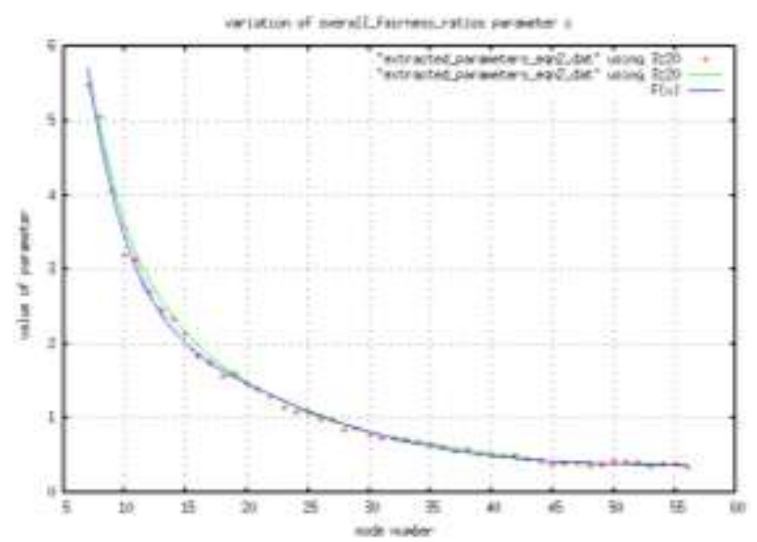

Figure 3: OFR parameter c

The potentially applicable equations are:

$$
\begin{aligned}
& \text { 1. } F(x)=((a * x+f) / \exp (b *(x-c)))+d \\
& \text { Ch_sq }=0.0215619 \\
& \text { 2. } F(x)=\left(\left(a * x^{2}+f\right) / \exp (b *(x-c))\right)+d \\
& \text { Ch_sq }=0.0173523 \\
& \text { 3. } F(x)=\left(\left(a * x^{3}+f\right) / \exp (b *(x-c))\right)+d \\
& \text { Ch_sq }=0.00903595 \\
& \text { 4. } F(x)=\left(\left(a * x^{4}+f\right) / \exp (b *(x-c))\right)+d \\
& \text { Ch_sq }=0.00711131 \quad \mathrm{~F}(80)=0.35171056 \\
& \mathrm{~F}(100)=0.351474 \quad \mathrm{~F}(120)=0.351468 \\
& \text { 5. } F(x)=\left(\left(a * x^{5}+f\right) / \exp (b *(x-c))\right)+d \\
& \text { Ch_sq }=0.0203594
\end{aligned}
$$

\section{Choice of best fit for OFR parameter c}

The equation in part 4 above has been selected because of both smallest reduced chi-square value obtained and good extendability. The parameters for best fit are:

$\mathrm{a}=0.000302874, \mathrm{~b}=0.228457, \mathrm{c}=2.29892$, $\mathrm{d}=0.351468, \mathrm{f}=14.9728$ 


\subsection{Trend Analysis - OFR parameter " $d$ ".}

The curve obtained depicts an increasing curve at a decreasing rate of increase, with increasing node numbers. This is typical of logarithmic curves.

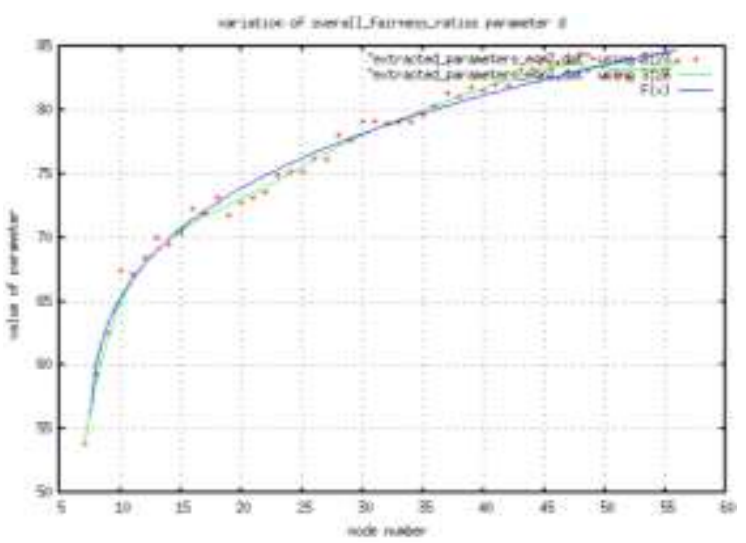

Figure 4: OFR parameter d

The potentially applicable equations are:

$$
\begin{aligned}
& \text { 1. } F(x)=a^{*} \log (b *(x-c))+d^{\star} x+f \\
& \text { Ch_sq }=0.992908 \quad \mathrm{~F}(80)=89.317657314 \\
& \mathrm{~F}(100)=92.513065155 \quad \mathrm{~F}(120)=95.429391556 \\
& \text { 2. } F(x)=a * \log (b *(x-c))+d^{*} x^{0.5}+f \\
& \text { Ch_sq }=0.965712 \quad \mathrm{~F}(80)=88.93058 \\
& \mathrm{~F}(100)=91.6850264 \quad \mathrm{~F}(120)=94.056896 \\
& \text { 3. } F(x)=a * \log (b *(x-c))+d * x^{0.3}+f \\
& \text { Ch_sq }=0.959342 \quad \mathrm{~F}(80)=88.692715 \\
& \mathrm{~F}(100)=91.2477246 \quad \mathrm{~F}(120)=93.39969138 \\
& \text { 4. } F(x)=a * \log (b *(x-c))+d * x^{0.25}+f \\
& \text { Ch_sq }=0.931535 \quad \mathrm{~F}(80)=88.700 \\
& \mathrm{~F}(100)=91.2568 \quad \mathrm{~F}(120)=93.406119 \\
& \text { 5. } F(x)=a * x^{0.5} * \log (b *(x-c))+d * x^{0.25}+f \\
& \text { Ch_sq }=1.74987 \quad \mathrm{~F}(80)=84.9890615 \\
& \mathrm{~F}(100)=84.610635 \quad \mathrm{~F}(120)=83.5811181
\end{aligned}
$$

\section{Choice of best fit for OFR parameter $d$}

The equation in part 4 above has been selected because of both smallest reduced chi-square value obtained and good extendability. The parameters for best fit are:

$a=3.55029, b=19.6346, c=7.18017, d=9.87662$, $\mathrm{f}=33.3688$

\section{Conclusion.}

This piece of investigation was meant to and has achieved the setting up of applicable models of trends of the parameters of equations for the metric OFR in a MANET topography of $300 \times 300 \mathrm{~m}^{2}$. These models which have been formulated using quite complex mathematical equations, will undoubtedly facilitate further study of MANETs for MAUC environment using software engineering concepts, successively formulating computational algorithms to be executed into simulators for conducive studies of MANET. This experiment was conducted in NS-2 over linux. The plottings and "fit" attempts were carried out in gnuplot, following which criteria adopted for selecting best fit have been reduced chi-square values and valid extendability of equations obtained.

Assumptions stated in former paper [21] are upheld in this paper also. Gnuplot and validity of its constructs are also assumed as appreciable.

Further work identified remain: formulating methods of predictability for metric OFR and its trend and reporting observations of certain critical values identified.

\section{References}

[1] M. Kaleem GALAMALI, Assoc. Prof Nawaz MOHAMUDALLY, Towards Dependable Pervasive Systems-A Position and Vision Paper, CEET 2014

[2] M. Kaleem GALAMALI, Assoc. Prof Nawaz MOHAMUDALLY, Model of Energy Savings achievable with Location-aware Node-to-Node Transmission in UbiComp , CEET 2014

[3] M. Kaleem GALAMALI, Assoc. Prof Nawaz MOHAMUDALLY, Model of Energy Savings achievable with Location-aware Node-to-Node Transmission in UbiComp Using Location Refresh Intervals, CEET 2014

[4] M. Kaleem GALAMALI, Assoc. Prof Nawaz MOHAMUDALLY, Model of Energy Savings achievable with Location-aware Transmission in UbiComp Using Relays, CEET 2014

[5] M. Kaleem GALAMALI, Assoc. Prof Nawaz MOHAMUDALLY, Mathematical modeling of need of exact number of relays to ensure seamless mobility in mobile computing, CEET 2014

[6] M. Kaleem GALAMALI, Assoc. Prof Nawaz MOHAMUDALLY, Modelling of need for multiple relays for ensuring seamless mobility, CEET 2014

[7] M. Kaleem GALAMALI, Assoc. Prof Nawaz MOHAMUDALLY, Investigation of prominence of placements of relays in a ubicomp topography,

[8] M. Kaleem GALAMALI, Assoc. Prof Nawaz MOHAMUDALLY, Model of energy savings achievable with location-aware transmission in ubicomp using optimised number of relays.

[9] M. Kaleem GALAMALI, Assoc. Prof Nawaz MOHAMUDALLY, Investigation of Prominence of Placements of Optimised Number of Relays in a Ubicomp Topography using Location-Aware Transmission, CEET 2015.

[10] M. Kaleem GALAMALI, Assoc. Prof Nawaz MOHAMUDALLY, Extending Node Battery Availability in Ubicomp with Location-Aware Transmission, CEET 2015.

[11] M. Kaleem GALAMALI, Assoc. Prof Nawaz MOHAMUDALLY, Extending Node Battery Availability in Ubicomp with Location-Aware Transmission using Location Refresh Intervals, CEET 2015.

[12] M. Kaleem GALAMALI, Assoc. Prof Nawaz MOHAMUDALLY, Extending Node Battery Availability in Ubicomp with Location-Aware Transmission using Uniformly Placed Relays, CEET 2015. 
[13] M. Kaleem GALAMALI, Assoc. Prof Nawaz MOHAMUDALLY, Extending Node Battery Availability in Ubicomp with Location-Aware Transmission Using Optimally Placed Relays, CEET 2015.

[14] M. Kaleem GALAMALI, Assoc. Prof Nawaz MOHAMUDALLY, Model of Sender Node Energy Savings Achievable with Location-Aware MANET Transmission in Ubicomp. ACCN 2016

[15] M. Kaleem GALAMALI, Assoc. Prof Nawaz MOHAMUDALLY, Model of Overall Node Energy Savings Achievable with Location-Aware MANET Transmission in Ubicomp. ACCN 2016

[16] M. Kaleem GALAMALI, Assoc. Prof Nawaz MOHAMUDALLY, Model of Sender Node Extra Energy Savings Achievable in MANET Against Direct Node-toNode Transmission Using Location-Aware Transmission in Ubicomp. ACCN 2016

[17] M. Kaleem GALAMALI, Assoc. Prof Nawaz MOHAMUDALLY, Model of Overall Node Extra Energy Savings Achievable in MANET against Direct Node-toNode Transmission Using Location-Aware Transmission in Ubicomp. ACCN 2016

[18] M. Kaleem GALAMALI, Assoc. Prof Nawaz MOHAMUDALLY, Model of Energy Consumption Ratio Achievable in MANET Using Location-Aware Transmission in Ubicomp. ACCN 2016

[19] M. Kaleem GALAMALI, Assoc. Prof Nawaz MOHAMUDALLY, Model of Minimum Energy Consumption Ratio Achievable in MANET Using LocationAware Transmission in Ubicomp. ACCN 2016

[20] M. Kaleem GALAMALI, Assoc. Prof Nawaz MOHAMUDALLY, Model of Maximum Energy Consumption Ratio Achievable in MANET Using LocationAware Transmission in Ubicomp. ACCN 2016

[21] M. Kaleem GALAMALI, Assoc. Prof Nawaz MOHAMUDALLY, Model of Overall Energy Consumption Fairness Ratio Achievable in MANET Using LocationAware Transmission in Ubicomp. ACCN 2016

[22] M. Kaleem GALAMALI, Assoc. Prof Nawaz MOHAMUDALLY, Model of Overall Energy Consumption Fairness Proportion Achievable in MANET Using LocationAware Transmission for Ubicomp, CEET 2016

[23] M. Kaleem GALAMALI, Assoc. Prof Nawaz MOHAMUDALLY, Model of Minimum Fairness Proportion Achievable in MANET Using Location-Aware Transmission for Ubicomp, CEET 2016

[24] M. Kaleem GALAMALI, Assoc. Prof Nawaz MOHAMUDALLY, Model of Maximum Fairness Proportion Achievable in MANET Using Location-Aware Transmission for Ubicomp, CEET 2016

[25] M. Kaleem GALAMALI, Assoc. Prof Nawaz MOHAMUDALLY, Model of Sender Fairness Proportion Achievable in MANET Using Location-Aware Transmission for Ubicomp, CEET 2016

[26] M. Kaleem GALAMALI, Assoc. Prof Nawaz MOHAMUDALLY, Model of Distance Travelled by packets in MANETs using Location-Aware Transmission for Ubicomp, CEET 2016

[27] M. Kaleem GALAMALI, Assoc. Prof Nawaz MOHAMUDALLY, Model of Maximum CBR Distance Travelled by packets in MANETs using Location-Aware Transmission for Ubicomp, CEET 2016

[28] M. Kaleem GALAMALI, Assoc. Prof Nawaz MOHAMUDALLY, Model of Minimum CBR Distance Travelled by packets in MANETs using Location-Aware Transmission for Ubicomp, CEET 2016

[29] M. Kaleem GALAMALI, Assoc. Prof Nawaz MOHAMUDALLY, Model of Range CBR Distance Experienced by Transmissions in MANETs using LocationAware Transmission for Ubicomp, CEET 2016

[30] M. Kaleem GALAMALI, Assoc. Prof Nawaz MOHAMUDALLY, Trend Analyses of Parameters of Equations for Sender Node Energy Savings Achievable in ubicomp MANETs using Location-Aware Transmission, ACCN 2017.

[31] M. Kaleem GALAMALI, Assoc. Prof Nawaz MOHAMUDALLY, Trend Analyses of Parameters of Equations for Overall Node Energy Savings Achievable in ubicomp MANETs using Location-Aware Transmission, ACCN 2017.

[32] M. Kaleem GALAMALI, Assoc. Prof Nawaz MOHAMUDALLY, Trend Analyses of Parameters of Equations for Sender Node Extra Energy Savings Achievable in MANET against Direct Node-to-Node Location-Aware Transmission, ACCN 2017.

[33] M. Kaleem GALAMALI, Assoc. Prof Nawaz MOHAMUDALLY, Trend Analyses of Parameters of Equations for Overall Nodes Extra Energy Savings Achievable in MANET against Direct Node-to-Node Location-Aware Transmission, ACCN 2017.

[34] M. Kaleem GALAMALI, Assoc. Prof Nawaz MOHAMUDALLY, Trend Analyses of Parameters of Equations for Energy Consumption Ratio Achievable in Ubicomp MANET Using Location-Aware Transmission, ACCN 2017.

[35] M. Kaleem GALAMALI, Assoc. Prof Nawaz MOHAMUDALLY, Trend Analyses of Parameters of Equations for Minimum Energy Consumption Ratio Achievable in Ubicomp MANETs Using Location-Aware Transmission, ACCN 2017.

[36] M. Kaleem GALAMALI, Assoc. Prof Nawaz MOHAMUDALLY, Trend Analyses of Parameters of Equations for Maximum Energy Consumption Ratio Achievable in Ubicomp MANETs Using Location-Aware Transmission, ACCN 2017.

[37] Markus Bylund and Zary Segall, Towards seamless mobility with personal servers, 2004.

[38] Masugi Inoue, Mikio Hasegawa, Nobuo Ryoki and Hiroyuki Morikawa, Context-Based Seamless Network and Application Control, 2004

[39] Xiang Song, Umakishore Ramachandran, MobiGo: A Middleware for Seamless Mobility, College of Computing Georgia Institute of Technology, Atlanta, GA, USA, August 2007

[40] Budzisz, Ferrús, R., Brunstrom A., Grinnemo, K, Fracchia, R., Galante, G., and Casadevall, F. Towards transport-laye mobility: Evolution of SCTP multihoming, March 2008

[41] Paul Dourish \& Genevieve Bell, Divining a digital future, 2011.

[42] Xiang Song, Seamless Mobility In Ubiquitous Computing Environments, PhD Thesis, Georgia Institute of Technology, August 2008

[43] Kevin O Mahony, Jian Liang, Kieran Delaney, User-Centric Personalization and Autonomous Reconfiguration Across Ubiquitous Computing Environments, NIMBUS Centre Cork Institute of Technology, Cork, Ireland, UBICOMM 2012

[44] Pablo Vidales, Seamless mobility in 4G systems, Technical Report, University of Cambridge, Computer Laboratory, Number 656, November 2005

[45] João Pedro Sousa and David Garlan, Aura: An Architectural Framework for User Mobility in Ubiquitous Computing Environments, School of Computer Science, Carnegie Mellon University, USA, August 2002

[46] Dennis Lupiana, Ciaran O'Driscoll, Fredrick Mtenzi, Defining Smart Space in the Context of Ubiquitous Computing, Dublin Institute of Technology, Ireland, Special Issue on ICIT 2009 Conference - Web and Agent Systems, 2009

[47] N.S.V.Shet1, Prof.K.Chandrasekaran2 and Prof. K.C.Shet3, WAP Based Seamless Roaming In Urban Environment with Wise Handoff Technique, International Journal of UbiComp (IJU), Vol.1, No.4, October 2010

[48] Yipeng Yu Dan He Weidong Hua Shijian Li Yu Qi Yueming Wang Gang Pan, FlyingBuddy2: A Braincontrolled Assistant for the Handicapped, Zhejiang University, UbiComp'12, September 5-8, 2012.

[49] Jing Su, James Scott, Pan Hui, Jon Crowcroft, Eyal de Lara Christophe Diot, Ashvin Goel, Meng How Lim, and Eben Upton, Haggle: Seamless Networking for Mobile Applications, 2007

[50] Rui Han, Moustafa M. Ghanem, Li Guo, Yike Guo*, Michelle Osmond, Enabling cost-aware and adaptive elasticity of multi-tier cloud applications, Future Generation Computer Systems, 2012

[51] Byrav Ramamurthy, K. K. Ramakrishnan, Rakesh K. Sinha, Cost and Reliability Considerations in Designing the Next- 
Generation IP over WDM Backbone Networks, 2012.

[52] Bhavish Aggarwal, Aditya Akella, Ashok Anand, Athula Balachandran, Pushkar Chitnis, Chitra Muthukrishnan, Ram Ramjee and George Varghese, EndRE: An End-System Redundancy Elimination Service for Enterprises, NSDI 2010, San Jose, CA

[53] Ashok Anand, Vyas Sekar and Aditya Akella, SmartRE: An Architecture for Coordinated Network-wide Redundancy Elimination, SIGCOMM 2009, Barcelona, Spain

[54] John Breeden II, "Smart-phone battery life could double without better batteries", Nov 14, 2012

[55] Andy Boxall, "When will your phone battery last as long as your kindle", December 5, 2012.

[56] Imielinski, T. and Navas, J.C. (1999). GPS-based geographic addressing, routing, and resource discovery. Comms. ACM, Vol. 42, No. 4, pp. 86-92.

[57] Hightower, J. and Borriello, G. (2001). Location Systems for Ubiquitous Computing. IEEE Computer, Vol. 34, No. 8, August, pp. 57-66.

[58] Harter, A., Hopper, A., Steggles, P., Ward, A. and Webster, P. (2002). The Anatomy of a Context-Aware Application. Wireless Networks, Vol. 8, No. 2-3, Mar-May, pp. 187-197.

[59] Hightower, J., Brumitt, B. and Borriello, G. (2002). The Location Stack: A Layered Model for Location in Ubiquitous Computing. Proceedings of the 4th IEEE Workshop on Mobile Computing Systems \& Applications (WMCSA 2002), Callicoon, NY, USA, June, pp. 22-28.

[60] Graumann, D., Lara, W., Hightower, J. and Borriello, G. (2003). Real-world implementation of the Location Stack: The Universal Location Framework. Proceedings of the 5th IEEE Workshop on Mobile Computing Systems \& Applications (WMCSA 2003), Monterey, CA, USA, October, pp. 122-128.

[61] Ko, Y., \& Vaidya, N. H. (2000). Location-aided routing (LAR) in mobile ad hoc networks. Wireless Networks, 6(4), 307-321.

[62] Liao, W.-H., Tseng, Y.-C., \& Sheu, J.-P. (2001). GRID: a fully location-aware routing protocol for mobile ad hoc networks. Telecommunication Systems, 18(1), 37-60.

[63] Kuhn, F., Wattenhofer, R., Zhang, Y., \& Zollinger, A. (2003). Geometric ad-hoc routing: of theory and practice. In Proceedings of the ACM (PODC'03) (pp. 63-72).

[64] Jiang, X., \& Camp, T. (2002). Review of geocasting protocols for a mobile ad hoc network. In Proceedings of the Grace Hopper Celebration (GHC).

[65] Ko, Y. \& Vaidya, N. H. (1999). Geocasting in mobile ad hoc networks: location-based multicast algorithms. In Proceedings of the IEEE (WMCSA '99) (pp. 101).

[66] Mauve, M., Fuler, H., Widmer, J., \& Lang, T. (2003). Position-based multicast routing for mobile ad-hoc networks (Technical Report TR-03-004). Department of Computer Science, University of Mannheim.

[67] Xu, Y., Heidemann, J., \& Estrin, D. (2001). Geographyinformed energy conservation for adhoc routing. In Proceedings of the ACM/IEEE (MOBICOM'01) (pp. 70-84).

[68] Hu, Y.-C., Perrig, A., \& Johnson, D. (2003). Packet leashes: a defense against wormhole attacks in wireless ad hoc networks. In Proceedings of the INFOCOM' 03 (pp. 19761986).

[69] Patwari, N., Hero III, A. O., Perkins, M., Correal, N. S., \& O’Dea, R. J. (2003). Relative location estimation in wireless sensor networks. IEEE Transactions on Signal Processing, 51(8), 2137-2148.

[70] Baldauf, M., Dustdar, S., \& Rosenberg, F. (2007). A Survey on Context Aware Systems. International Journal of Ad Hoc and Ubiquitous Computing, Inderscience Publishers. forthcoming. Pre-print from: http://www.vitalab.tuwien.ac.at/ florian/papers/ijahuc2007.pdf

[71] Hong, D., Chiu, D.K.W., \& Shen, V.Y. (2005). Requirements elicitation for the design of context-aware applications in a ubiquitous environment. In Proceedings of ICEC'05 (pp. 590-596).

[72] Neeraj Tantubay, Dinesh Ratan Gautam and Mukesh Kumar Dhariwal, A Review of Power Conservation in Wireless Mobile Ad hoc Network (MANET)", International Journal of computer Science Issues, Vol 8, Issue 4, No 1, July 2011

[73] Wenrui Zhao, Mostafa Ammar and Ellen Zegura, "A Message Ferrying Approach for Data Delivery in Sparse Mobile Ad Hoc Networks", MobiHoc'04, May 24-26, 2004, Roppongi, Japan.

About Author (s):

Associate Professor Nawaz Mohamudally works at University of Technology, Mauritius (UTM) and has undertaken supervision of MPhil/PhD Students for many years.

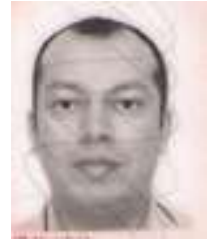

M. Kaleem Galamali is a part-time student (achieved M Phil Transfer on 28.10.2014, currently $\mathrm{PhD}$ student) at UTM under supervision of A.P. Nawaz Mohamudally. 